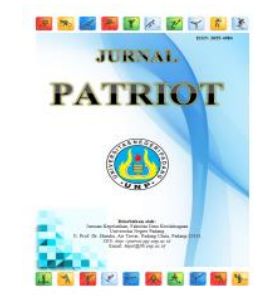

\title{
Jurnal Patriot
}

ISSN Online: 2714-6596 ISSN Cetak: 2655-4984

Home: http://patriot.ppj.unp.ac.id/index.php/patriot

Volume 3 Nomor 3 Tahun 2021 (Halaman 284-291)

DOI: $10.24036 /$ patriot.v\%vi\%i.798

Analisis Tingkat Kelincahan Atlet Tenis Meja PTM MBC Raflesia

\section{Yahya Eko Nopiyanto ${ }^{1 *}$, Septian Raibowo ${ }^{2}$, Andika Prabowo ${ }^{3}$, Doni Milion Gunawantara ${ }^{4}$ Ibrahim $^{5}$}

\author{
1,2,3,4 Program Studi Pendidikan Jasmani, Fakultas Keguruan dan Ilmu Pendidikan, Universitas \\ Bengkulu, Indonesia \\ ${ }^{5}$ Fakultas Ilmu Keolahragaan, Universitas Cenderawasih, Papua, Indonesia \\ Email Korespondensi: yahyaekonopiyanto@unib.ac.id
}

Informasi Artikel:

Dikirim: 24 Juni 2021 Direvisi: 11 Agustus 2021 Diterbitkan: 1 September 2021

\begin{abstract}
ABSTRAK
Tulisan ini bertujuan untuk mengetahui tingkat kelincahan atlet tenis meja PTM MBC Raflesia. Metode yang digunakan dalam penelitian ini adalah deskriptif kuantitatif. Populasi dalam penelitian ini adalah seluruh atlet putra tenis meja di klub PTM MBC Raflesia dengan jumlah sebanyak 30 orang. Teknik sampling yang digunakan adalah total sampling, sehingga seluruh populasi menjadi sampel penelitian. Instrumen dan teknik pengambilan data dalam penelitian adalah Hexagonal test. Teknik analisis data menggunakan statistik deskriptif dengan pengklasifikasian dibagi menjadi lima kategori yaitu: sangat kurang, kurang, sedang, baik, sangat baik, yang kemudian dituangkan dalam bentuk persentase. Hasil penelitian menunjukan bahwa bahwa secara umum 13,33\% atlet berada pada kategori sangat kurang; $16,67 \%$ berada pada kategori rendah, $30 \%$ berada pada kategori sedang; $36,67 \%$ berada pada katagori baik; 3,33\% berada pada kategori sangat baik. Jadi dapat disimpulkan bahwa tingkat kelincahan atlet tenis meja PTM MBC Raflesia berada pada kategori baik.
\end{abstract}

Kata Kunci: kelincahan; atlet; tenis meja

\section{Analysis of he Agility Level of PTM MBC Raflesia Table Tennis Athletes} ABSTRACT

This study aims to determine the level of agility of PTM MBC Raflesia table tennis athletes. The method used in this research was descriptive quantitative. The population in this study were all PTM MBC Raflesia table tennis athletes with a total of 30 people. The sampling technique used was total sampling, so that the entire population became the research sample. The instrument and data collection technique in this research was the Hexagonal test. The data analysis technique used descriptive statistics with classification divided into five categories which were then poured in the form of percentages. The results showed that in general $13.33 \%$ of athletes were in the very poor category; $16.67 \%$ were in the low category, $30 \%$ were in the medium category; $36.67 \%$ were in the good category; $3.33 \%$ were in the very good category. So it can be concluded that the level of agility of PTM MBC Raflesia table tennis athletes was in the good category.

Keywords: agility, athletes, table tennis

\section{PENDAHULUAN}

Tenis meja merupakan salah satu permainan dengan menggunakan bola kecil yang dilakukan di atas meja, serta dilakukan dengan intensitas permainan yang cepat. Pada dasarnya permainan ini di awali dengan memantulkan bola terlebih dahulu di atas meja, memukul ke arah lawan dengan melewati atas net (Carrasco et al., 2010; 
Tomoliyus, 2012). Untuk dapat mencapai prestasi yang optimal dalam permainan tenis meja dibutuhkan beberapa komponen fisik yang baik diantaranya adalah komponen kelincahan. Menurut (Mahendra, 2014) menyatakan bahwa kelincahan merupakan kompenen fisik yang sangat penting dan menentukan prestasi atlet tenis meja. Semakin baik tingkat kelincahan atlet akan memudahkan atlet dalam melakukan gerakan yang sulit, terhindar dari cedera saat berlatih maupun bertanding, dan mudah bergerak ke berbagai arah serta cepat dalam melakukan mengantisipasi bola dari lawan (Darojat et al., 2019).

Berbagai hasil penelitian sebelumnya mengungkapkan bahwa pemain tenis meja yang mempunyai kelincahan tinggi akan sangat mudah untuk mengubah arah gerak badan ke berbagai posisi berbeda dengan kecepatan tinggi (Syamsudin, 2012). Terdapat hubungan yang positif signifikan antara kelincahan yang dimiliki oleh seorang pemain tenis meja dengan keterampilan yang dimilikinya (Sukamto, 2011; Saleh, 2012; Irawan, 2019). Artinya semakin baik kelincahan atlet maka akan semakin baik pula keterampilan bermain yang dimilikinya.

Berdasarkan hasil obervasi yang dilakukan oleh peneliti di klub PTM MBC Raflesia, Kota Bengkulu diketahui bahwa masih terdapat pemain tenis meja yang hanya mementingkan teknik dan mengenyampingkan kelincahan itu sendiri, masih terdapat pemain yang kesulitan mengantisipasi datangnya pukulan bola dari lawan bertanding, terdapat pemain yang kurang cepat dalam melakukan pukulan, hasil pukulan masih sering mengenai net, serta lambat dalam melakukan blok. Lebih lanjut, peneliti juga melakukan wawancara tidak terstruktur kepada pelatih yang menyatakan bahwa para pemain sering mengikuti kejuaraan tingkat daerah di Kota Bengkulu namun belum mendapatkan prestasi yang optimal di tingkat nasional.

Mengingat pentingnya kelincahan yang harus dimiliki oleh pemain tenis meja, maka perlu dilakukan penelitian mengenai tingkat kelincahan pemain tenis meja di klub PTM MBC Raflesia Kota Bengkulu. Keterbaruan dalam penelitian ini adalah menghasilkan analisis yang kritis yang belum pernah dilakukan sebelumnya di klub PTM MBC Raflesia Kota Bengkulu. Sehingga hasil penelitian ini akan mempermudah pelatih dalam menggali informasi mengenai kondisi fisik para atlet, dan membantu pelatih dalam menyiapkan program latihan untuk meningkatkan kelincahan atlet di klub PTM MBC Raflesia Kota Bengkulu.

\section{METODE}

Jenis penelitian yang digunakan adalah deskriptif kuantitatif yaitu penelitian yang menggambarkan keadaan yang terjadi di dalam komunitas (Budiwanto, 2017). Lokasi penelitian terletak di gedung Hall Bentiring Permai, Kecamatan Muara Bangka Hulu, Kota Bengkulu. Sedangkan waktu pelaksanaan penelitian pada bulan Juni 2021. Populasi yang menjadi bagian dari penelitian ini adalah semua atlet putra tenis meja yang terlibat aktif di klub PTM MBC Raflesia, Kota Bengkulu dengan jumlah sebanyak 30 atlet. Total sampling digunakan dalam penelitian ini, sehingga seluruh populasi menjadi sampel penelitian. Instrumen dan teknik pengambilan data dalam penelitian 
adalah Hexagonal test. Adapun prosedur penelitian yang dilakukan adalah menyiapkan alat-alat yang dibutuhkan untuk penelitian, menyiapkan instrumen penelitian, berkoordianasi dengan pelatih dan pemain terkait pengambilan data penelitian, menjelaskan cara pelaksanaan dan tujuan penelitian kepada atlet, pelaksanaan pengambilan data, menganalisis data penelitian. Statistik deskriptif dengan pengklasifikasian yang terdiri dari lima kategori yang kemudian dituangkan dalam bentuk persentase digunakan untuk menganalisis data. Untuk pengkategorian menggunakan acuan lima batasan kategori (Darojat et al., 2010) yang dituangkan dalam tabel 1 berikut ini:

Tabel 1. Tabel Kategori

\begin{tabular}{ccc}
\hline No & Rentangan Nilai & Kategori \\
\hline 1 & $\mathrm{X}>\mathrm{M}+1,5 \mathrm{SD}$ & Sangat kurang \\
2 & $\mathrm{M}+0,5 \mathrm{SD}<\mathrm{X} \leq \mathrm{M}+1,5 \mathrm{SD}$ & Kurang \\
3 & $\mathrm{M}-0,5 \mathrm{SD}<\mathrm{X} \leq \mathrm{M}+0,5 \mathrm{SD}$ & Sedang \\
4 & $\mathrm{M}-1,5 \mathrm{SD}<\mathrm{X} \leq \mathrm{M}-0,5 \mathrm{SD}$ & Baik \\
5 & $\mathrm{X}>\mathrm{M}-1,5 \mathrm{SD}$ & Sangat baik \\
\hline
\end{tabular}

Keterangan :

$$
\begin{aligned}
& \mathrm{M}=\text { mean } \\
& \mathrm{X}=\text { Skor } \\
& \mathrm{SD}=\text { standar deviasi }
\end{aligned}
$$

Setelah data dikelompokkan dalam setiap kategori, langkah selanjutnya yang ditempuh oleh peneliti adalah menghitung persentase dengan formula dari (Budiwanto, 2017) sebagai berikut:

$$
\mathrm{P}=\frac{F}{N} \times 100 \%
$$

Keterangan :

$\mathrm{P}=$ Persentase

$\mathrm{F}=$ Frekuensi

$\mathrm{N}=$ Jumlah Sampel

\section{HASIL}

Penyajian hasil penelitian bertujuan untuk memberikan gambaran tentang data atau informasi dari data yang diperoleh dan dituangkan dalam tabel maupun diagram batang sehingga dapat dimengerti oleh pembaca. 
Tabel 2. Tingkat Kelincahan Atlit Tenis Meja PTM MBC Raflesia

\begin{tabular}{llccc}
\hline No & \multicolumn{1}{c}{ Kategori } & Skor & Frekuensi & Persentasi \\
\hline 1 & Sangat kurang & $\mathrm{X}>14,10$ & 4 & $13,33 \%$ \\
2 & Kurang & $12,37<\mathrm{X}>14,10$ & 5 & $16,67 \%$ \\
3 & Sedang & $10,63<\mathrm{X}<12,37$ & 9 & $30 \%$ \\
4 & Baik & $8,90<\mathrm{X}<10,63$ & 11 & $36,67 \%$ \\
5 & Sangat baik & $\mathrm{X}>8,90$ & 1 & $3,33 \%$ \\
\hline
\end{tabular}

Berdasarkan tabel 2 dapat diketahui bahwa tingkat kelincahan atlet PTM MBC Raflesia, Kota Bengkulu terdiri dari 4 atlet atau 13,33\% berada pada kategori sangat kurang, 5 atlet atau 16,67\% berada pada kategori kurang baik, 9 atlet atau 30\% berada pada kategori sedang, 11 atlet atau 36,67\% berada pada kategori baik dan, 1 atlet berada pada kategori sangat baik. Tingkat kelincahan atlet tenis meja PTM MBC Raflesia dapat dilihat pada diagram batang di bawah ini.

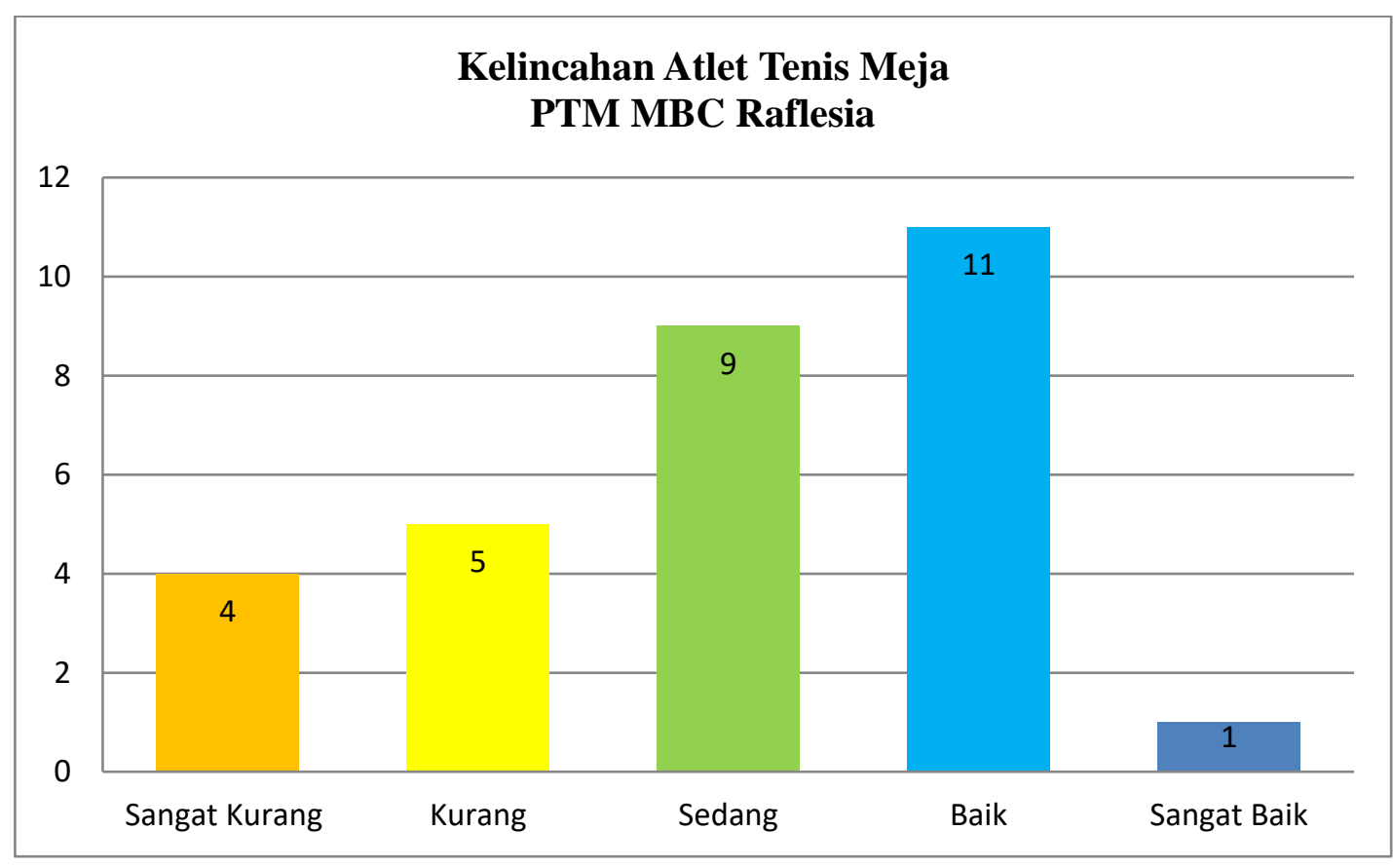

Diagram 1. Diagram Batang Tingkat Kelincahan Atlet Tenis Meja PTM MBC Raflesia

\section{PEMBAHASAN}

Tingkat kelincahan atlet tenis meja di klub PTM MBC Raflesia menunjukan bahwa tingkat kelincahan berada pada kategori sangat kurang dengan frekuensi sebanyak 4 atlet atau 13,33\%. Atlet yang berada dalam kategori sangat kurang merupakan atlet pemula yang mempunyai berat badan yang obesitas atau kurang ideal, sehingga hasil tes kelincahan berada pada kategori sangat kurang. Hal tersebut dapat jelaskan melalui hasil penelitian sebelumnya yang menyatakan bahwa terdapat 
hubungan yang signifikan antara indeks masa tubuh dengan kelincahan seorang atlet (Untoro \& Kurniawati, 2017; Dewi, 2020; Santika \& Subekti, 2020). Selain itu, berat badan yang kurang ideal berhubungan dengan status gizi yang dimiliki oleh orang tersebut. Sebagaimana (Asmilyadi \& Yendrizal, 2020) menyatakan bahwa status gizi memberikan dampak positif terhadap prestasi. Begitu juga dengan indeks masa tubuh mampu memberikan sumbangsih sebesar 95\% terhadap kelincahan seorang atlet (Pranata, 2019). Lebih lanjut diketahui bahwa terdapat korelasi positif signifikan antara aktivitas fisik dengan tingkat kelincahan atlet (Sholihah \& Wahyuni, 2018).

Terdapat $16,67 \%$ atau 5 atlet di klub PTM MBC Raflesia yang berada dalam kategori kurang. Setelah dilakukan analisis diketahui bahwa atlet dalam kategori ini merupakan atlet pemula yang berusia antara 10 hingga 12 tahun. Atlet pemula dalam klub ini masih minim pengalaman bertanding, belum pendapatkan perhatian atau pelatihan khusus dari pelatih dalam meningkatkan kelincahan. Jadi, tidak mengejutkan jika atlet pemula mempunyai tingkat kelincahan yang kurang. Hasil penelitian yang dilakukan oleh (Alsyiahbana, 2013) menyebutkan bahwa usia atlet 12 tahun berada pada kategori kurang. Pada usia 10 hingga 12 tahun merupakan periode yang penting dalam perkembangan motorik anak, dan pada masa ini biasanya anak-anak belum mendapatkan spesialisasi keterampilan olahraga (Lengga et al., 2020; Pratama et al, 2021). Dalam arti kata lain pada masa ini merupakan proses menuju penyempurnaan keterampilan dasar olahraga. Selain itu, pada usia 8-12 tahun merupakan masa bagi anak untuk bermain, menikmati permainan, dan tahap untuk belajar menguasai keterampilan dari olahraga yang sedang ditekuni (Burhein, 2017).

Atlet tenis meja di klub PTM MBC Raflesia juga menunjukkan tingkat kelincahan pada kategori sedang dengan frekuensi sebanyak 30\% atau 9 atlet. Secara umum usia atlet yang berada pada kategori sedang berusia 16 tahun dan telah mempunyai beberapa kali pengalaman bertanding di level daerah, namun belum pernah mendapatkan medali emas di kejuaran yang pernah diikuti, sehingga belum mempunyai kondisi fisik yang baik. Seperti yang diketahui bahwa kondisi fisik atlet tenis meja perlu diperhatikan lebih lanjut oleh pelatih dan pembina. Oleh sebab itu, sangat disarankan bagi pelatih untuk mampu mengembangkan serta menerapkan program latihan untuk meningkatkan kondisi fisik atlet yang dibinanya tanpa meninggalkan aspek teknik yang benar (Ikhsan \& Masrun, 2020). Salah satu kondisi fisik yang perlu diperhatikan oleh pelatih adalah kelincahan atlet tenis meja, hal ini penting karena kelincahan mempengaruhi kecepatan atlet dalam merubah posisi dalam permainann tenis meja (Saleh, 2018).

Sebanyak 11 atau 36,67\% atlet di di klub PTM MBC Raflesia mempunyai kelincahan yang baik. Berdasarkan analisis data diketahui bahwa atlet yang berada pada kategori baik secara umum berusia antara 17 hingga 25 tahun, mempunyai pengalaman bertanding yang lebih banyak, pernah mendapatkan berbagai medali di kejuaraan yang pernah diikutinya. Hal ini senada dengan hasil kajian dari (Permadi, 2017) menyatakan bahwa atlet yang secara konsisten berlatih dan mempunyai pengalaman bertanding cenderung mempunyai kelincahan yang baik. Usia mempunyai hubungan yang 
signifikan positif antara kelincahan dengan keterampilan bermain tenis meja (Horníková, Doležajová, \& Zemková, 2018; Suwo, 2020). Kelincahan yang baik sangat dibutuhkan dalam olahraga permainan yang menggunakan bola seperti tenis meja (Zemkova \& Hamar, 2014).

Berdasarkan penelitian diketahui bahwa hanya terdapat 1 atlet yang mempunyai kelincahan dalam kategori sangat baik. Setelah dilakukan analisis lebih lanjut diketahui bahwa atlet yang mempunyai kategori sangat baik merupakan atlet yang berusia 25 tahun, mempunyai pengalaman bertanding di tingkat nasional, pernah mendapatkan medali emas di kejuaraan nasional sehingga mempunyai kelincahan yang sangat baik. Kelincahan merupakan komponen penting dan harus menjadi perhatian penting bagi para pelatih dan atlet tenis meja, karena dengan adanya kelincahan yang baik maka atlet akan lebih mudah dalam mengikuti latihan dan pertandingan (Putra et al., 2015).

\section{KESIMPULAN}

Simpulan dalam penelitian ini adalah tingkat kelincahan atlet tenis meja di klub PTM MBC Raflesia berada dalam kategori baik. Peneliti menyadari bahwa penelitian ini mempunyai keterbatasan diantaranya adalah hanya berfokus pada kelincahan, dan jumlah sampel yang digunakan dalam skala kecil. Disarankan untuk peneliti selanjutnya disarankan dapat menambahkan komponen fisik yang lain seperti kecepatan dan kekuatan otot lengan.

\section{DAFTAR PUSTAKA}

Alsyahbana, M. (2013). Profil Tinggi Badan, Daya Ledak (Power) Otot Tungkai, Kelincahan (Agility) Dan Daya Tahan (Endurance) Atlet Bulutangkispb Surya Baja Surabayausia 12-16 Tahun. Jurnal Kesehatan Olahraga, l(1).

Anisa Sholihah, W. A. H. Y. U., \& Wahyuni, S. (2018). Hubungan Antara Aktivitas Fisik Dengan Tingkat Kelincahan Pada Remaja (Doctoral dissertation, Universitas Muhammadiyah Surakarta).

Asmilyadi, R. (2020). Hubungan antara Kemampuan Vo2max dan Status Gizi dengan Hasil Belajar Penjasorkes Siswa di SMA Negeri 2 Kerinci. Jurnal Patriot, 2(2), 537-548. DOI: https://doi.org/10.24036/patriot.v2i1.656

Budiwanto, S. (2017). Metode Penelitian Dalam Keolahragaan. Malang: UM Press.

Burhaein, E. (2017). Aktivitas Fisik Olahraga Untuk Pertumbuhan Dan Perkembangan Siswa SD. Indonesian Journal of Primary Education. https://doi.org/10.17509/ijpe.v1i1.7497

Carrasco, L., Pradas, F., Floría, P., Martínez, A., Herrero, R., \& González Jurado, J. A. (2010). Grip strength in young top-level table tennis players. International Journal of Table Tennis Sciences, (6). Retrieved from http://www.old.ittf.com/ittf_science/SSCenter/Int_Journal6/docs/_064.pdf 
Darojat, F. A., \& Hariadi, I. (2019). Pengaruh Latihan Speed Ladder Terhadap Peningkatan Kelincahan pada Peserta Ekstrakurikuler Tenis Meja. Indonesia Performance Journal, 3(1), 33-38.

Gusti Ayu Agung Nina Utari Dewi, \& I Gusti Putu Ngurah Adi Santika. (2020). Korelasi Berat Badan dan Kekuatan Otot Tungkai terhadap Kelincahan Tubuh Siswa Pencak Silat. Jurnal Kejaora (Kesehatan Jasmani Dan Olah Raga), 5(1), 14-19. https://doi.org/10.36526/kejaora.v5i1.838

Horníková, H., Doležajová, L., \& Zemková, E. (2018). Playing table tennis contributes to better agility performance in middle-aged and older subjects. Acta Gymnica, 48(1), 15-20. DOI: 10.5507/ag.2018.004

Ikhsan, M., \& Masrun, M. Koordinasi Mata Tangan dan Kelentukan Togok Berhubungan dengan Kemampuan Smash Tenis Meja. Jurnal Patriot, 2(2), 399408. DOI: https://doi.org/10.24036/patriot.v2i1.553

Irawan, E. (2019). Pengaruh Kelincahan, Kecepatan Gerak Dan Kelentukan Terhadap Ketepatan Pukulan Forehand Drive Pada Permainan Tenis Meja Siswa Sma Negeri 3 Maros. Jurnal Pendidikan Olahraga, 9(2), 19-29.

Lengga, S. W., ADI, S., \& FADHLI, N. R. (2020). Metode Latihan Drill Untuk Meningkatkan Keterampilan Backhand Overhead Clear Pada Atlet Bulutangkis Usia 8-12 Tahun. Indonesia Performance Journal, 4(2).

Mahendra, I. R. (2014). Faktor Kondisi Fisik Dominan Penentu Prestasi Bermain Tenis Meja (Analisis Faktor Fleksibilitas Pergelangan Tangan, Fleksibilitas Pinggul, Waktu Reaksi, Koordinasi Mata Tangan, Kelincahan, Dan Power Otot Lengan Pada Mahasiswa Pembinaan Prestasi Tenis (Doctoral dissertation, UNS (Sebelas Maret University).

Permadi, A. G. (2017). Survey Tingkat Kondisi Fisik Atlet Bulutangkis PB. Pahlawan Sumenep. Jurnal Ilmiah Mandala Education, 3(2), 71-80. DOI: http://dx.doi.org/10.36312/jime.v3i2.160

Pranata, D. Y. (2019). Indeks Massa Tubuh Dengan Kelincahan Pemain Futsal Stkip Bbg. Altius: Jurnal Ilmu Olahraga dan Kesehatan, 8(2). OI: https://doi.org/10.36706/altius.v8i2.8987

Pratama, H. G., Santika, I. G. P. N. A., \& Santoso, D. A. (2021). Profil Motorik Kasar Kelas Rendah SDN 1 Sumbergedong Trenggalek. Jurnal Pendidikan Kesehatan Rekreasi, 7(1), 160-166. https://doi.org/10.5281/zenodo.4446274

Putra, J., Nuzuli, N., \& Masri, M. (2015). Hubungan Power Otot Lengan dengan Keterampilan Bermain Tenis Meja pada Klub Atlet Indonesia Muda Tahun 2013. Jurnal Ilmiah Mahasiswa Pendidikan Jasmani, Kesehatan dan Rekreasi, 1(2). 
Saleh, M. S. (2012). Hubungan antara kekuatan lengan, kelincahan, dan kecepatan reaksi tangan dengan kemampuan bermain tenis meja pada siswa SMP Negeri 23 Makassar. Competitor: Jurnal Pendidikan Kepelatihan Olahraga,4(2). DOI: https://doi.org/10.26858/com.v4i2.710

Saleh, A. (2018). Profil Atlet Tenis Meja Klub FKKSP. Jurnal Patriot, 86-93. DOI: https://doi.org/10.24036/patriot.v0i0.16

Santika, I. G. P. N. A., \& Subekti, M. (2020). Hubungan Tinggi Badan dan Berat Badan terhadap Kelincahan Tubuh Atlit Kabaddi. Jurnal Pendidikan Kesehatan Rekreasi, 6(1), 18-24. https://doi.org/10.5281/zenodo.3661565

Sukamto, A. (2011). Hubungan Antara Kekuatan Lengan, Kelincahan, Dan Kecepatan Reaksi Tangan Dengan Kemampuan Bermain Tenis Meja Pada Siswa Smp Negeri 2 Kabupaten Gowa. Competitor: Jurnal Pendidikan Kepelatihan Olahraga, 3(3). DOI: https://doi.org/10.26858/com.v3i3.674

Suwo, R. (2020). Correlation Between Agility and Athletes Topspin of Table Tennis in Kendari City. JUARA: Jurnal Olahraga, 5(1), 55-65. DOI: https://doi.org/10.33222/juara.v5i1.770

Syamsuddin, N. (2012). Hubungan Antara Kekuatan Lengan, Kelincahan, Dan Kecepatan Reaksi Tangan Dengan Kemampuan Bermain Tenismeja Pada Siswa Sma Negeri Sungguminasa. Competitor: Jurnal Pendidikan Kepelatihan Olahraga, 4(3). DOI: https://doi.org/10.26858/com.v4i3.733

Tomoliyus, M. S (2012). Sukses Melatih Keterampilan Dasar Permainan Tenis Meja Dan Penilaian. Jawa Tengah: CV. Sarnu Untung.

Untoro, F. S., \& Kurniawati, D. (2017). Hubungan Antara Indeks Massa Tubuh Dengan Kelincahan Dan Volume Oksigen Maksimum Pada Pemain Futsal MUFC Karanganyar (Doctoral dissertation, Universitas Muhammadiyah Surakarta).

Zemková, E., \& Hamar, D. (2014). Agility performance in athletes of different sport specializations. Acta Gymnica, 44(3), 133-140. DOI: 10.5507/ag.2014.013 